\title{
Retrospective and prospective model simulations of sea level rise impacts on Gulf of Mexico coastal marshes and forests in Waccasassa Bay, Florida
}

\author{
Laura Geselbracht • Kathleen Freeman • \\ Eugene Kelly • Doria R. Gordon • Francis E. Putz
}

Received: 25 June 2010 / Accepted: 31 March 2011 / Published online: 10 May 2011

(C) The Author(s) 2011. This article is published with open access at Springerlink.com

\begin{abstract}
The State of Florida (USA) is especially threatened by sea level rise due to extensive low elevation coastal habitats (approximately 8,000 $\mathrm{km}^{2}<1 \mathrm{~m}$ above sea level) where the majority of the human population resides. We used the Sea Level Affecting Marshes Model (SLAMM) simulation to improve understanding of the magnitude and location of these changes for 58,000 ha of the Waccasassa Bay region of Florida's central Gulf of Mexico coast. To assess how well SLAMM portrays changes in coastal wetland systems resulting from sea level rise, we conducted a hindcast in which we compared model results to 30 years of field plot data. Overall, the model showed the same pattern of coastal forest loss as observed. Prospective runs of SLAMM using $0.64 \mathrm{~m}, 1 \mathrm{~m}$ and $2 \mathrm{~m}$ sea level rise scenarios predict substantial changes over this century in the area covered by coastal wetland systems including net losses of coastal forests $(69 \%, 83 \%$, and $99 \%$, respectively) and inland forests $(33 \%, 50 \%$, and $88 \%)$, but net gains of tidal flats $(17 \%, 142 \%$, and 3,837\%). One implication of these findings at the site level is that undeveloped, unprotected lands inland from the coastal forest should be protected to accommodate upslope migration of this natural community in response to rising seas. At a broader scale, our results suggest that coastal wetland systems will be unevenly affected across the Gulf of Mexico as sea level rises. Species vulnerable to these anticipated changes will experience a net loss or even elimination.
\end{abstract}

\author{
Abbreviations \\ DEM digital elevation model \\ ESA Endangered Species Act
}

L. Geselbracht $(\varangle) \cdot$ K. Freeman · E. Kelly · D. R. Gordon

The Nature Conservancy, Florida Chapter, 222 S. Westmonte Drive Suite 300,

Altamonte Springs, FL 32714-4269, USA

e-mail: lgeselbracht@tnc.org

F. E. Putz

Department of Biology, University of Florida, PO BOX 118526 Gainesville, FL 32611-8526, USA 


$\begin{array}{ll}\text { FDEP } & \text { Florida Department of Environmental Protection } \\ \text { FLUCFCS } & \text { Florida Land Use, Cover and Forms Classification System } \\ \text { FNAI } & \text { Florida Natural Areas Inventory } \\ \text { FWC } & \text { Florida Fish and Wildlife Conservation Commission } \\ \text { IPCC } & \text { Intergovernmental Panel on Climate Change } \\ \text { LiDAR } & \text { light detection and ranging } \\ \text { NOAA } & \text { National Oceanic and Atmospheric Administration } \\ \text { NWI } & \text { National Wetlands Inventory } \\ \text { SLAMM } & \text { Sea Level Affecting Marshes Model } \\ \text { SLR } & \text { sea level rise } \\ \text { SWFWMD } & \text { Southwest Florida Water Management District } \\ \text { US EPA } & \text { US Environmental Protection Agency }\end{array}$

\section{Introduction}

Coastal wetland systems will be substantially affected whether sea level rises $18-59 \mathrm{~cm}$ by 2100 , as predicted by the IPCC (2007), or at the higher rates predicted by models that include the melting of polar ice caps and other factors (e.g., CCSP 2008; Mitrovica et al. 2009; Overpeck et al. 2006; Rahmstorf et al. 2007). Estuaries are especially vulnerable to environmental changes because their productivity varies with the qualities and quantities of waters from both the adjacent sea and uplands. Many Gulf of Mexico estuaries are bounded by heavily urbanized lands, which will limit the opportunities for intertidal and coastal wetland systems to migrate to higher elevations in response to sea level rise (SLR; Harris and Cropper 1992). SLR impacts will be observable over decadal time scales, which is within the planning horizons for coastal development. Clearly, continued development in areas that will be directly affected by SLR is ill-advised for both human and natural communities. Clarification of how SLR is likely to affect the distribution of coastal wetland systems will improve our understanding of how species dependent on those systems may be affected and provide decision makers with opportunities to make better decisions regarding development, conservation, and restoration. Better decisions now will result in healthier natural and human communities into the future.

Among the tools developed to enhance our understanding the effects of SLR on coastal wetland systems is the Sea Level Affecting Marshes Model (SLAMM). SLAMM was developed in the mid-1980s (Park et al. 1986), with SLAMM 6.0.1 released in May 2010 (http://warrenpinnacle.com/prof/SLAMM/index.html). SLAMM employs a decision tree that incorporates geometric and qualitative relationships to simulate the dominant processes involved in wetland change and shoreline modifications during SLR. The four primary processes used to predict wetland fate with SLR are inundation, erosion, overwash, and saturation. This model has been applied around the USA (Glick and Clough 2006), but several applications to date have used relatively low resolution (1.5 m contours) National Elevation Data (NED), which requires SLAMM to extrapolate elevations based on land cover data such as provided by the National Wetlands Inventory (NWI). Comparison of SLAMM results using inferred elevation information versus the recently available high resolution Light Detection and Ranging (LiDAR) elevation data revealed 
differences in predicted habitat distributions of up to $173 \%$ depending on the habitat type (Geselbracht et al. unpublished data).

Until recently, validation of SLAMM simulations was limited by the inability to conduct retrospective analyses or "hindcasts" due to model and data limitations. The most recent version (SLAMM 6.0.1 beta) now allows for retrospective analyses. This feature is useful for examining how well SLAMM simulates the effects of SLR that have already been documented. Field data collection over the past two decades along the Waccasassa Bay section of the Big Bend Coast of northern peninsular Florida (Williams et al. 1999; DeSantis et al. 2007) allows such an evaluation.

Florida's Gulf of Mexico coast, with extreme low relief geomorphology, is particularly vulnerable to SLR. Along much of the coastline the $1 \mathrm{~m}$ elevation contour extends inland from the shore for 3 to $10 \mathrm{~km}$. While much of Florida's Gulf Coast has been substantially developed, the marshy Big Bend region has experienced relatively little development. The eight counties comprising this region, which represents approximately one-fifth of Florida's coastline, have a combined population of only 900,000 , or about $6 \%$ of the state's population, which is otherwise concentrated in coastal areas (US Census Bureau 2010). The Big Bend Coast is particularly well suited for a SLAMM analysis because of its relatively undeveloped status, stable position with respect to SLR (i.e., there is virtually no subsidence or rebound; Williams et al. 2007), lack of large-scale freshwater withdrawals, microtidal and low energy sea conditions, and availability of historic tide gauge data.

We conducted both retrospective and prospective SLAMM analyses for an approximately 58,000 ha area surrounding and including Waccasassa Bay Preserve State Park in the Big Bend region of Florida (Fig. 1), where physical SLR impacts on coastal forests have been tracked for nearly two decades. We compare the results of our SLAMM hindcast with those from data from 13 permanent plots monitored since 1992 (DeSantis et al. 2007; Williams et al. 1999). The field studies focused on the patterns, processes, and rates of coastal forest conversion into salt marsh, revealing that high elevation sites that are only inundated by Gulf water during storm surges support forest with up to 20 tree species. In contrast, Sabal palmetto (cabbage palm) and Juniperus virginiana (southern red cedar) are the only tree species remaining on sites that are tidally inundated 10-27 times per year; all tree regeneration ceases when the frequency of tidal inundation exceeds 13 times per year (DeSantis et al. 2007; Williams et al. 1999).

Process-based greenhouse studies (Williams et al. 1998) coupled with field experiments (Williams et al. 2007) revealed that the observed high rates of tree mortality resulted primarily from increases in soil water salinity with increased frequencies of tidal inundation. Additionally, the process of forest replacement by saltmarsh, which was most rapid in the lowest elevation plots, was accelerated by the 1998-2002 drought (DeSantis et al. 2007; Williams et al. 2003).

For both the prospective and retrospective analyses, we used the recently available high resolution LiDAR-derived elevation data, which has a vertical accuracy in wetland and forest systems of $\pm 0.30 \mathrm{~m}$ (at the 95 th percentile confidence interval for each individual cell in the map, corresponding to a root mean square error of $0.15 \mathrm{~m}$ ) and a vertical accuracy of $\pm 0.115 \mathrm{~m}$ (at the $95 \%$ confidence level using RMSE(r) $\times$ 1.7308). More information on vertical and horizontal accuracy of LiDAR data can be found in "ASPRS Guidelines Vertical Accuracy Reporting for LiDAR Data V1.0." (http://www.asprs.org/society/committees/lidar/downloads/vertical_accuracy_ 


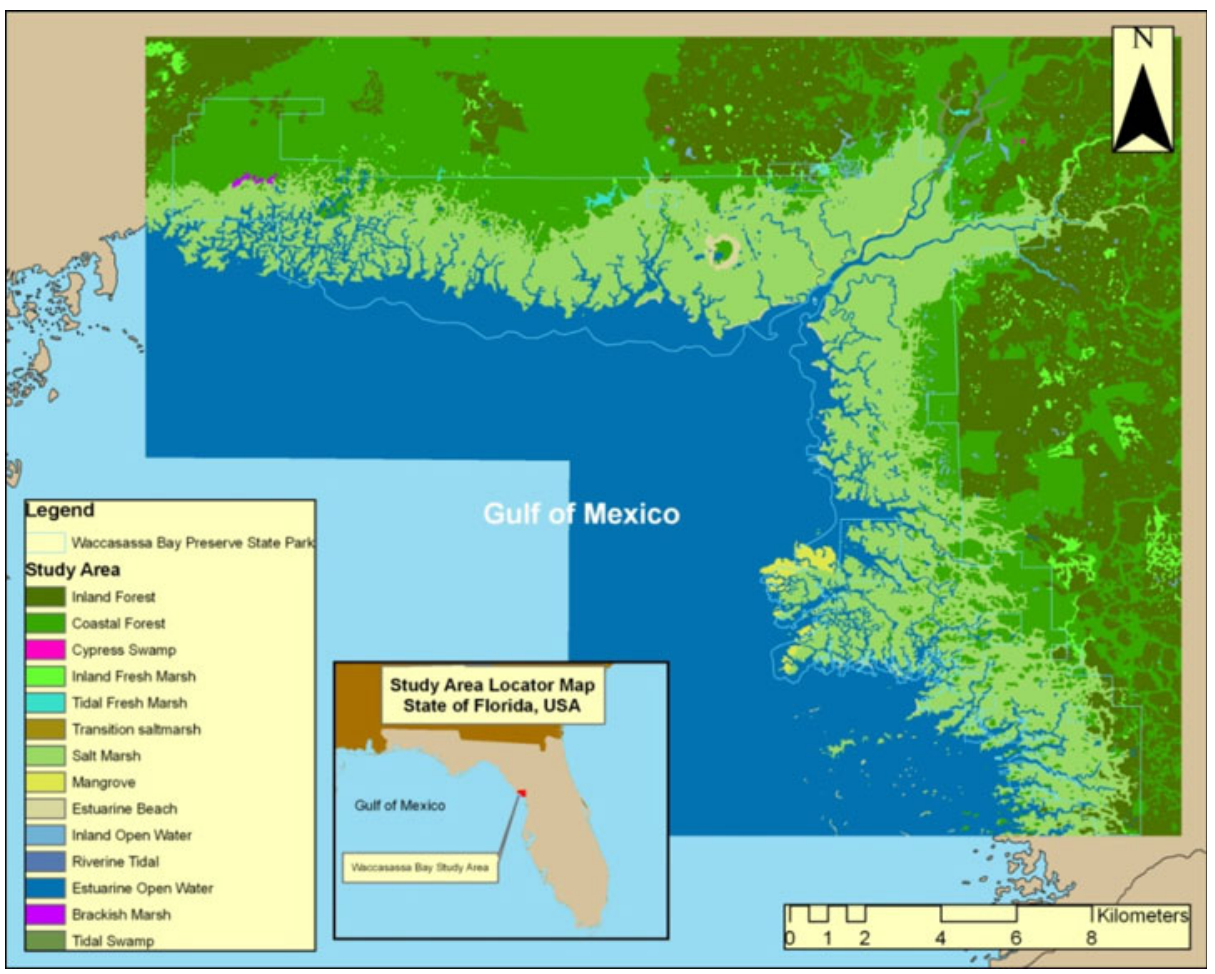

Fig. 1 Study area (58,000 ha), which includes the Waccasassa Bay Preserve State Park, State of Florida, USA and all adjacent areas at or below $2 \mathrm{~m}$ in elevation

reporting_for_lidar_data.pdf) and the NOAA Digital Coast website (http://www.csc. noaa.gov/digitalcoast/data/coastallidar/index.html), respectively.

Our prospective application of SLAMM evaluates the impacts of $0.64 \mathrm{~m}, 1 \mathrm{~m}$, and $2 \mathrm{~m}$ SLR by the year 2100. In addition, we identify the species likely to be most vulnerable to the predicted changes in coastal wetland distribution, provide some preliminary interpretation of how these changes may affect those species, and account for the extent of habitat loss expected to occur as a result of future land development activities. These data should inform the development of potential adaptation strategies that can be employed proactively to minimize or mitigate potential adverse impacts on these species.

\section{Study site and methods}

\subsection{Study site}

Waccasassa Bay Preserve State Park $\left(29^{\circ} 7^{\prime}\right.$ N, $82^{\circ} 47^{\prime} \mathrm{W}$; Fig. 1) includes 12,488 ha of tidal flats, oyster bars, saltmarshes, and coastal forests distributed from just below sea level to just over $1.4 \mathrm{~m}$ NAVD88. Open water salinities in the adjacent Gulf are 
typically low due to high rainfall (1300 $\mathrm{mm}$ per annum), freshwater discharge from the Waccasassa River, and the proximity ( $88 \mathrm{~km}$ north) of the Suwannee River. The entire Park is underlain by a stable carbonate platform and, with the exception of

Table 1 Input parameters used for the SLAMM retrospective and prospective runs

\begin{tabular}{|c|c|c|}
\hline Description & Hindcast & Forecast \\
\hline Land cover photo date ${ }^{a}$ & 1983,1984 & 2004 \\
\hline DEM date b $^{\mathrm{b}}$ & 1983,1984 & 2007 \\
\hline Direction offshore [N, S, E, W] & $\mathrm{W}, \mathrm{S}$ & $\mathrm{W}, \mathrm{S}$ \\
\hline Historic trend in sea level rise $(\mathrm{mm} / \mathrm{year})^{\mathrm{c}}$ & 1.8 & 1.8 \\
\hline NAVD correction [mean tide level-NAVD $88(\mathrm{~m})^{\mathrm{d}}$ & -0.0495 & -0.0452 \\
\hline Great diurnal tide range $(\mathrm{m})^{\mathrm{e}}$ & 1.158 & 1.158 \\
\hline Salt elevation $(\mathrm{m} \text { above MTL })^{\mathrm{f}}$ & 0.814197 & 0.814197 \\
\hline Marsh erosion rate (horizontal $\mathrm{m} /$ year) ${ }^{\mathrm{g}}$ & 0.23 & 0.23 \\
\hline Swamp (AKA coastal forest) erosion rate (horizontal m/year) ${ }^{\mathrm{g}}$ & 0.23 & 0.23 \\
\hline Tidal flat erosion rate (horizontal m/year) ${ }^{\mathrm{g}}$ & 0.23 & 0.23 \\
\hline Saltmarsh accretion rate $(\mathrm{mm} / \mathrm{year})^{\mathrm{h}}$ & 7.2 & 7.2 \\
\hline Brackish marsh accretion rate $(\mathrm{mm} / \mathrm{year})^{\mathrm{h}}$ & 7.2 & 7.2 \\
\hline Tidal freshwater marsh accretion rate $(\mathrm{mm} / \mathrm{year})^{\mathrm{h}}$ & 7.2 & 7.2 \\
\hline Beach sedimentation rate $(\mathrm{mm} / \mathrm{year})^{\mathrm{h}}$ & 7.2 & 0 \\
\hline Frequency of overwash (years) ${ }^{\mathrm{i}}$ & 25 & 25 \\
\hline Used elevation pre-processor [true, false] & False & False \\
\hline
\end{tabular}

Subsites were created based on direction offshore and date of land cover photo (i.e., two subsites were required for the prospective analysis and four subsites were required for the retrospective analysis)

${ }^{\text {a}}$ For the hindcast run, the 1983 and 1984 NWI wetland maps were used. For prospective runs, the more recent 2004 SWFWMD land use and cover dataset was used

${ }^{b}$ For both the hindcast and forecast runs, the LiDAR-derived DEM was used for the elevation data. The DEM date is, however, set to the same value as the land cover photo date so that the model run will represent the time period of interest. Differences in sea level for the hindcast runs as compared to the forecast runs is taken into account in the NAVD correction. See footnote $\mathrm{d}$ below

${ }^{\mathrm{c}}$ NOAA Tides and Currents website (http://tidesandcurrents.noaa.gov/)

${ }^{\mathrm{d}}$ NAVD correction is MTL-NAVD88 in meters. For the forecast runs, the NAVD correction was calculated from data found at the above referenced website. For the hindcast runs, the NAVD correction was adjusted to $-0.0495 \mathrm{~m}$ based on observed sea level rise of $1.80 \mathrm{~mm} /$ year for the 23 -year period 1984 to 2007

${ }^{\mathrm{e}}$ Great diurnal tide range (mean higher high water minus mean lower low water). Data are from the NOAA Tides and Currents website url referenced above

${ }^{\mathrm{f} S a l t}$ elevation (AKA mean high water spring), the elevation at which freshwater marsh or dry land begins, was calculated by examining 2 years of tide data for the Cedar Key tide station (NOAA tides and currents website). MHWS equates to the height of tide at which inundation occurs no more than once per month. The Cedar Key station was used as the source of tide data because it was the most proximate with recent historic tide data. We calculated a frequency distribution of the tide data and selected the elevation that occurred no more than once per month

${ }^{\mathrm{g}}$ The closest data for our study site came from Hine and Belknap (1986). They found that saltmarsh eroded at a rate of $23 \mathrm{~cm}$ per year for coastal embayments approximately $27 \mathrm{~km}$ south of Waccasassa Bay in the Crystal Bay area. We used the same rate for swamp and tidal flat erosion

${ }^{\mathrm{h}}$ The closest data for our study area come from Leonard et al. (1995) who reported that saltmarsh accretes at $7.2 \mathrm{~mm}$ per year (in Cedar Creek, approximately $27 \mathrm{~km}$ south in Crystal Bay, Citrus County, Florida)

${ }^{\mathrm{i}}$ Although we supplied a frequency of overwash value as an input parameter for these runs, this variable is not relevant for coasts without barrier islands and has no bearing on the results 
timber harvests in the adjacent uplands, there has been little physical or hydrologic alteration in the area. For the purposes of the modeling, we identified a study area of 58,000 ha that entirely encompasses the State Park and includes all adjacent areas at or below 2 m elevation (Fig. 1).

\subsection{Methods for SLAMM analyses}

The most recent version of SLAMM (6.0.1 beta; Clough et al. 2010) was modified by the developer to make hindcasting possible and to allow specific years to be designated as output, rather than requiring fixed time steps. In all scenarios run for this paper, the soil saturation algorithm was turned off, the connectivity algorithm was enabled, and the SLAMM default elevations for coastal wetland system types were utilized. Documentation for version 6.0.1 (beta) is available at the following URL (http://warrenpinnacle.com/prof/SLAMM6/SLAMM6_Technical_ Documentation.pdf).

As in previous versions, SLAMM 6.0.1 (beta) requires a set of raster input files, a table of site parameters specific to the study site, and a set of model parameters that are entered when a simulation is run. In this study, the raster inputs were a digital elevation model (DEM), a slope layer, and a natural communities layer (Table 1). To produce a spatial map of offshore directions and dates for the natural communities input maps, we used "subsites" (defined polygons over which site parameters are held constant) within SLAMM to run the analyses (Fig. 2). The DEM and slope were held constant for each scenario. The NWI vegetation maps dated 1983 or 1984 were used as the natural communities input map for the hindcast. Suwannee River Water Management District (SRWMD) and Southwest Florida Water Management District (SWFWMD) land use/land cover data from 2004 were used as the natural communities input for the prospective analyses. Only two subsites were required for the forecasts to accommodate the two offshore directions of the site (south and west).

Two additional changes were made to the hindcast inputs to accommodate the retrospective aspects of the model run based on recommendations of the model developer (J. Clough, personal communication). Because we used LiDAR elevation data from 2007, we adjusted the NAVD correction to accommodate the observed

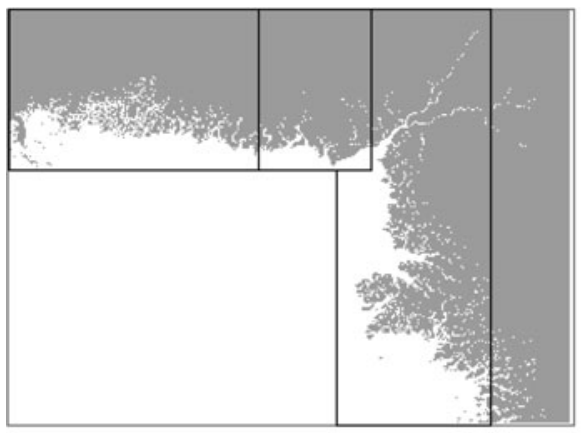

Hindcast subsites

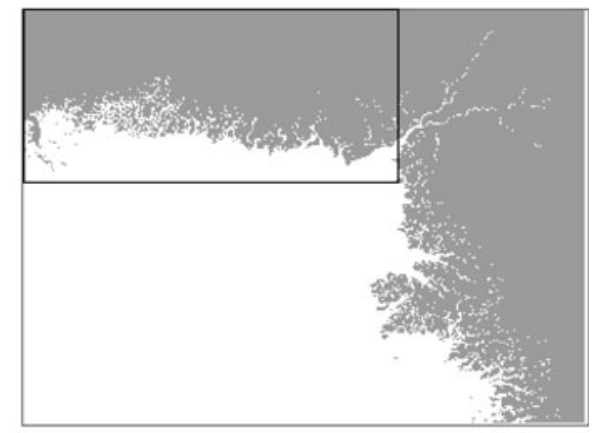

Forecast subsites

Fig. 2 Subsites used in the hindcast and forecast SLAMM runs. Subsites were required to handle study area variations in the direction offshore (south and west) and, in the case of the hindcast, also photo date for the photo-interpreted land use, land cover geospatial dataset used (1983 and 1984) 
SLR of $1.80 \mathrm{~mm} / \mathrm{yr}$ for the 23 year period 1984 to $2007(-0.0495 \mathrm{~m})$. Then to avoid the model also attempting to correct the DEM on the basis of SLR for the period 1984 to 2007, as it would do automatically, the date of the DEM was changed to match the subsite NWI data. These changes were made to compensate for the lack of a historical DEM that would form the basis for "hindcasting."

DEM/slope LiDAR data collected for Levy County in 2007 were obtained from the Florida Division of Emergency Management (FDEM) Coastal LiDAR Project. The data were downloaded as a DEM from the NOAA Coastal Services Center's Digital Coast website. The DEM was downloaded in State Plane Coordinate System (NAD83) with a vertical datum NAVD88, a $5 \mathrm{~m}$ cell size (Data Class = Ground), and employing the average bin method to obtain bare earth elevation. Downloaded floating point tiles were converted to a grid and mosaicked, resampled to $10 \mathrm{~m}$ cell size, and clipped to the study area. LiDAR and surveyed elevations for the field plots were compared using a paired $t$ test $(n=13)$. Areas of open ocean and tidal creeks that contained "no data" values were set equal to 0 . We then derived a slope raster in degrees from the DEM.

Vegetation For the hindcast, NWI data were used and each wetland polygon was assigned a SLAMM land cover category based on the NWI attribute field. The category assignment was based on a lookup table provided as SLAMM documentation. For NWI types that were not in the lookup table, the NWI code was assigned a category based on the translation information in the SLAMM 6.0 technical documentation (Table 2). Some polygons that were assigned "mangrove" by the lookup table were not mangrove and were manually assigned to SLAMM "swamp" (coastal forest) or saltmarsh categories based on a review of aerial photography. Most of the forested islands within the saltmarsh had NWI codes that were assigned the "transitional saltmarsh" category by the lookup table. The SLAMM category "transitional saltmarsh" is an intermediate habitat between coastal forest and saltmarsh. In Waccasassa Bay, most of the forest islands support the same tree species found in depauperate coastal forest landward of the saltmarsh and are coded by SLAMM as "swamp." Because of the similarity in species composition, the forest islands were categorized as "swamp" for input to the model.

For the prospective analyses, we used land use/land cover data based on 2004 aerial photography. These data use the Florida Land Use, Cover and Forms Classification System (FLUCFCS) to classify land (see http://growth-management. alachua.fl.us/conservation/metadata/srlu95.htm). FLUCFCS categories were examined and assigned the SLAMM category that most closely matched the vegetation or land use description. FLUCFCS polygons assigned to the "mangrove" category were verified by consultation with Waccasassa Bay Preserve State Park staff.

Table 2 Terminology used by SLAMM to describe coastal habitat in the study area

\begin{tabular}{ll}
\hline Coastal wetland system & SLAMM category \\
\hline Coastal forest & Swamp \\
Tree island (embedded in salt marsh) & Swamp or transitional saltmarsh \\
Inland forest & Undeveloped dry land \\
Inland or tidal freshwater marsh & Inland or tidal fresh marsh \\
\hline
\end{tabular}


Site specific input parameters The non-spatial, site specific input parameters required to run SLAMM include the photo date of the land cover layer, the date the DEM was created, direction offshore that the sub-site faces, historic trend in sea level rise, several tidal elevation parameters (NAVD88 correction, salt elevation, and great diurnal tide range) and the rates of erosion, sedimentation, and accretion. These input parameters were obtained from a number of sources and are detailed in the Table 1 footnotes.

Model runs Coastal wetland systems in Waccasassa Bay occur at elevations somewhat lower than the typical elevations used by SLAMM due to the system's high freshwater head. This area is a major discharge zone for the Floridan Aquifer (SRWMD 2006), which underlies most of the Florida peninsula. In all of the model runs, LiDAR-derived elevation data were used; therefore, use of the SLAMM preprocessor was not required.

For the hindcast analysis, we ran SLAMM using observed SLR for the period 1984 to 2008 (4.3 cm total). This rate of SLR is based on the tide gauge information collected at Cedar Key, Florida, which forms the northern point of Waccasassa Bay (NOAA Tides and Currents website, http://tidesandcurrents.noaa.gov/). We assumed the historic SLR trend calculated for Cedar Key was representative of the rate for our study area for the retrospective study period. For our prospective analyses, we ran SLAMM using $0.64 \mathrm{~m}, 1 \mathrm{~m}$, and $2 \mathrm{~m}$ SLR by the year 2100. The $0.64 \mathrm{~m}$ SLR scenario was chosen to allow a comparison with the results of Castaneda and Putz (2007). The other two SLR scenarios were selected based on recent projections of the magnitude of SLR to the year 2100 (CCSP 2008; Mitrovica et al. 2009; Overpeck et al. 2006; Rahmstorf et al. 2007).

Model output SLAMM provides output in both tabular and graphic formats. For the 1984-2008 hindcast, we set the model to provide output at 5-8 year intervals. For each output SLAMM predicts the areal extent of each wetland system type, so change in wetland distribution over time can be calculated by comparing output to the initial condition. The graphic output provides a spatial depiction of where habitat changes are simulated to occur. As with the tabular output, change over time can be described quantitatively and qualitatively by comparing initial condition with output years.

\subsection{Comparison with field studies}

We quantified the SLAMM hindcast results for each field plot and compared these results with field plot data reported in DeSantis et al. (2007) to determine the extent to which SLAMM was able to portray known SLR change. Quantitative comparison of the hindcast projection with the field results was not possible because DeSantis et al. (2007) reported tree status and regeneration at each site but did not spatially quantify their results.

\subsection{Prospective analysis of vulnerable flora and fauna}

We used spatial data on land cover, species distributions, and species-specific habitat requirements to identify species expected to be affected by the habitat 
losses predicted by SLAMM. Species lists compiled for the Waccasassa Bay area (Florida Department of Environmental Protection 2005; The Nature Conservancy and University of Florida Geoplan Center 2005) were used to identify rare or imperiled species that inhabit areas predicted to be impacted. We did not attempt to make predictions about the long-term population viability of species likely to be affected by sea level rise. Predictions about future population viability would require range-wide analyses of habitat changes, demographic rates, dispersal ability, and other factors.

\section{Results}

\subsection{SLAMM hindcast results}

The SLAMM hindcast for 1984-2008 showed substantial changes ( $>5 \%$ in categories $>100 \mathrm{ha})$ in area for five coastal wetland systems: coastal forest $(-32 \%)$; transitional saltmarsh $(+2,670$ ha from 0 ha); saltmarsh $(+12 \%)$; and inland freshwater marsh $(-30 \%$; Table 3$)$. In addition, a substantial loss of inland forest $(-6 \%)$ was predicted. Most of the changes occurred at the ecotones between salt marsh and coastal forest, where the latter community was converted into saltmarsh and transitional saltmarsh (Fig. 3).

Our hindcast of the Williams et al. (2007) field sites showed the same patterns of change as the full study area. These predicted changes were consistent with those

Table 3 Results of hindcast-change in study area coastal wetland system distributions 1984 to 2008 based on the observed rate of sea level rise during this period (1.80 mm per year)

\begin{tabular}{|c|c|c|c|c|c|c|}
\hline & $\mathrm{IC}$ & $\begin{array}{l}\text { T0 } \\
\text { (1984) }\end{array}$ & $\begin{array}{l}\% \text { Change } \\
\text { IC to T0 }\end{array}$ & 2008 & $\begin{array}{l}\text { Change IC } \\
\text { to } 2008\end{array}$ & $\begin{array}{l}\text { \% Change IC } \\
\text { to } 2008\end{array}$ \\
\hline (eustatic) $\mathrm{m}$ & 0 & & & 0.0273 & & \\
\hline Developed dry land & 0 & 0 & & 0 & 0 & \\
\hline \multicolumn{7}{|l|}{ Coastal wetland system } \\
\hline Inland forest & 9,083 & 8,600 & $-5 \%$ & 8,516 & -568 & $-6 \%$ \\
\hline Coastal forest & 9,901 & 6,936 & $-30 \%$ & 6,768 & $-3,134$ & $-32 \%$ \\
\hline Cypress swamp & 3 & 3 & $0 \%$ & 3 & 0 & $0 \%$ \\
\hline Inland freshwater marsh & 552 & 407 & $-26 \%$ & 389 & -163 & $-30 \%$ \\
\hline Tidal freshwater marsh & 44 & 22 & $-51 \%$ & 22 & -23 & $-51 \%$ \\
\hline Transitional saltmarsh & 0 & 3,594 & & 2,670 & 2,670 & \\
\hline Saltmarsh & 8,971 & 8,901 & $-1 \%$ & 10,070 & 1,100 & $12 \%$ \\
\hline Mangrove & 163 & 160 & $-2 \%$ & 158 & -4 & $-3 \%$ \\
\hline Estuarine beach & 110 & 110 & $0 \%$ & 104 & -6 & $-5 \%$ \\
\hline Tidal flat & 0 & 69 & & 94 & 94 & \\
\hline Inland open water & 113 & 91 & $-20 \%$ & 33 & -80 & $-71 \%$ \\
\hline Riverine tidal & 26 & 17 & $-36 \%$ & 1 & -25 & $-95 \%$ \\
\hline Estuarine open water & 18,194 & 18,230 & $0 \%$ & 18,320 & 126 & $1 \%$ \\
\hline Brackish marsh & 14 & 69 & $403 \%$ & 60 & 46 & $336 \%$ \\
\hline Tidal swamp & 47 & 14 & $-70 \%$ & 14 & -33 & $-70 \%$ \\
\hline
\end{tabular}

Initial condition (IC) represents the distributions of wetland systems based on the 1984 NWI map. Time 0 (T0, in this case 1984) is the coastal wetland system distribution based on SLAMM's interpretation of which should occur at a given elevation. Elevation data for this hindcast is a DEM based on LiDAR. Units are in hectares unless otherwise stated. OW stands for "open water" 
(a)

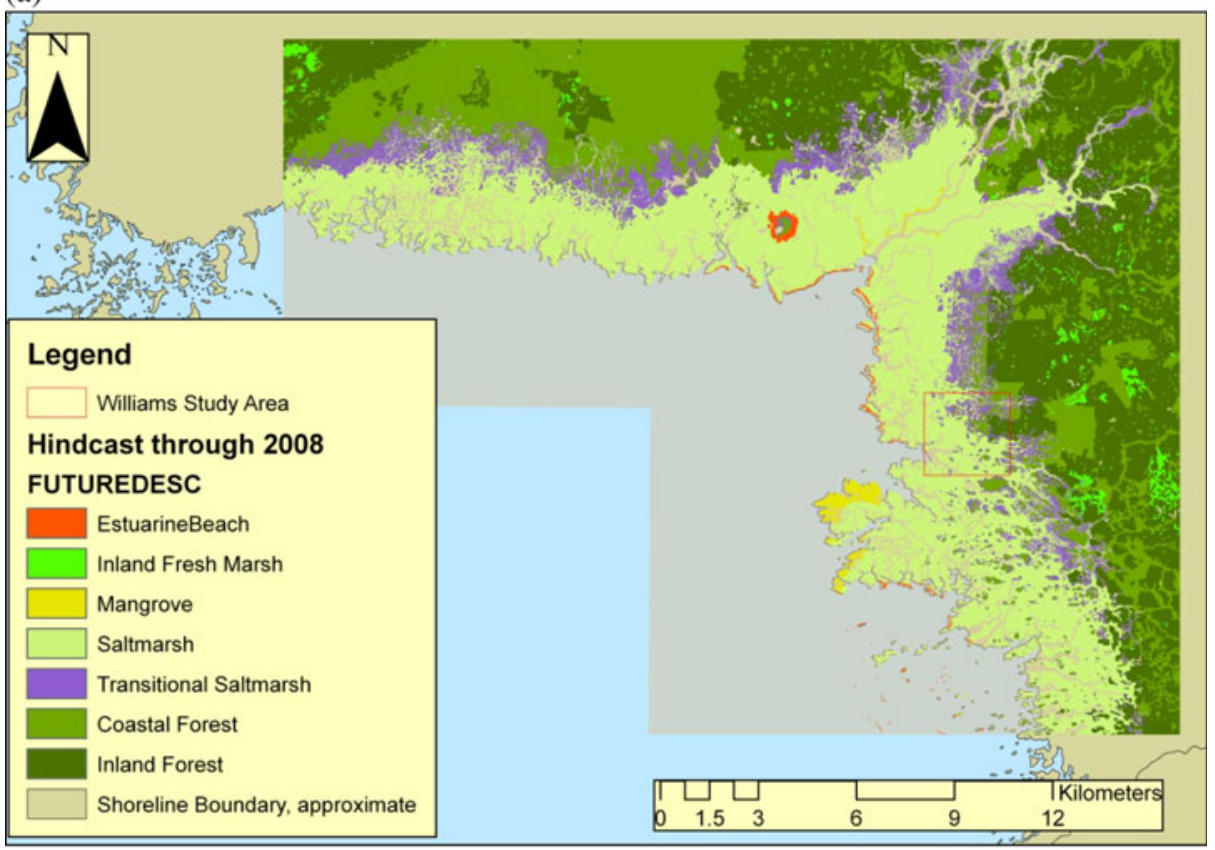

(b)

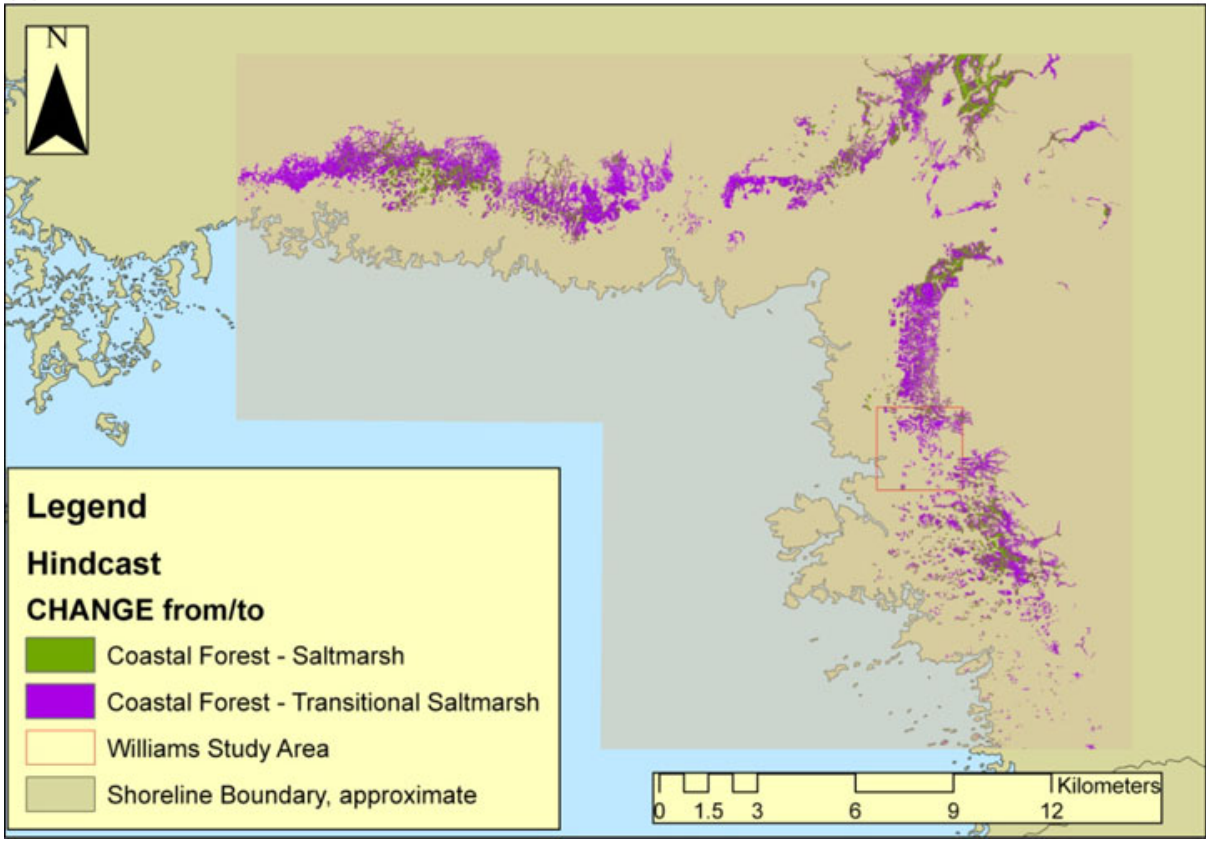

Fig. 3 Results of SLAMM hindcast 1984 to 2008. The study area is shown with location of permanent plots highlighted. a Modeled distribution of coastal wetland systems in 2008. b Changes in coastal wetland system distribution $>1 \%$ of the study area 
Table 4 Percent loss of coastal forest from Williams et al. (1999) field sites

\begin{tabular}{llclcl}
\hline $\begin{array}{l}\text { Field } \\
\text { site }\end{array}$ & $\begin{array}{l}\text { Elevation } \\
(\mathrm{m} \mathrm{NAVD})\end{array}$ & $\begin{array}{l}\text { Initial condition } \\
\text { (IC), coastal } \\
\text { forest }\end{array}$ & $\begin{array}{l}\text { IC to 2004 change } \\
\text { in coastal forest to } \\
\text { transitional saltmarsh }\end{array}$ & $\begin{array}{l}\text { IC to 2004 change, } \\
\text { coastal forest change } \\
\text { to saltmarsh }\end{array}$ & $\begin{array}{l}\text { Percent loss of } \\
\text { coastal forest } \\
\text { (IC to 2004) }\end{array}$ \\
\hline H0 & 0.96 & 47,000 & 17,400 & 3,300 & $44 \%$ \\
H1 & 0.93 & 7,100 & 2,800 & 400 & $45 \%$ \\
H2 & 0.78 & 10,300 & 5,400 & 1,100 & $63 \%$ \\
H3 & 0.80 & 12,600 & 8,200 & 800 & $71 \%$ \\
I2 & 0.67 & 6,100 & 2,300 & 300 & $43 \%$ \\
C1 & 1.1 & 7,300 & 0 & 0 & $0 \%$ \\
C2 & 1.09 & 4,800 & 800 & 300 & $23 \%$ \\
C3 & 0.69 & 5,800 & 2,900 & 1,000 & $67 \%$ \\
\hline
\end{tabular}

Initial condition (IC) represents coastal wetland ecosystems as characterized by 1983 and 1984 National Wetlands Inventory maps. Units are in square meters

${ }^{a}$ Elevations are from Williams et al. (1999)

documented in the field studies (DeSantis et al. 2007; Williams et al. 2007; Table 4). The model predicted that a substantial portion of the "healthy" tree island stands in the Williams et al. (2007) study sites (H0-H3), one "intermediate" condition stand (I2), and one contiguous inland forest stand (C3) would transition from coastal forest into transitional saltmarsh and saltmarsh (Table 4). DeSantis et al. (2007) demonstrated the loss of the more salt tolerant tree species such as Sabal palm (Sabal palmetto), Southern red cedar (Juniperus virginiana), and live oak (Quercus virginiana) from tree islands. Only the highest elevation field site (C1) and the highest elevation portions of the other field sites with an NWI initial condition of coastal forest (H0-H3, I2 and C1-C3) did not transition in the hindcast (Fig. 4). DeSantis et al. (2007) recorded a loss of the less salt tolerant oak species at field site C1 during the 2000 to 2005 time period. The "decadent" stands (D1-D3) and intermediate stands (I1 and I3) were not identified as "coastal forest" in the NWI initial condition map, but rather as "saltmarsh." Consequently, our results did not show these areas transitioning from "coastal forest" to "saltmarsh." DeSantis et al. (2007) records these sites as relict and recently relict stands (as of 2000 to 2005 time period). A comparison of the surveyed elevations in the Williams et al. (2007) field sites (mean of $0.77 \mathrm{~m}$; std $=0.19$ ) with the LiDAR elevations in these same plots (mean of $0.74 \mathrm{~m}$; std $=0.14$ ) revealed no significant difference $(\mathrm{t}=0.34$, $\mathrm{df}=12$, $\mathrm{p}=0.74)$.

\subsection{Prospective SLAMM results}

Even the most conservative prospective SLAMM simulation (0.64 $\mathrm{m}$ of SLR by $2010)$ predicted substantial change $(>5 \%$ and $>100$ ha) for the 100 year period ending in 2100 (Table 5). According to this scenario, coastal wetland system types experiencing substantial change in the 58,000 ha study area included transitional saltmarsh $(+42 \%)$, coastal forest $(-69 \%)$, saltmarsh $(+13 \%)$, and inland fresh marsh $(-24 \%)$. In addition, inland forest decreased by $33 \%$ in the study area.

Under the $1 \mathrm{~m}$ SLR scenario, coastal wetland types experiencing substantial change include saltmarsh $(+104 \%)$, coastal forest $(-83 \%)$, transitional saltmarsh $(+3669$ ha from 0 ha $)$, tidal flat $(+142 \%)$ and inland freshwater marsh $(-41 \%)$ 


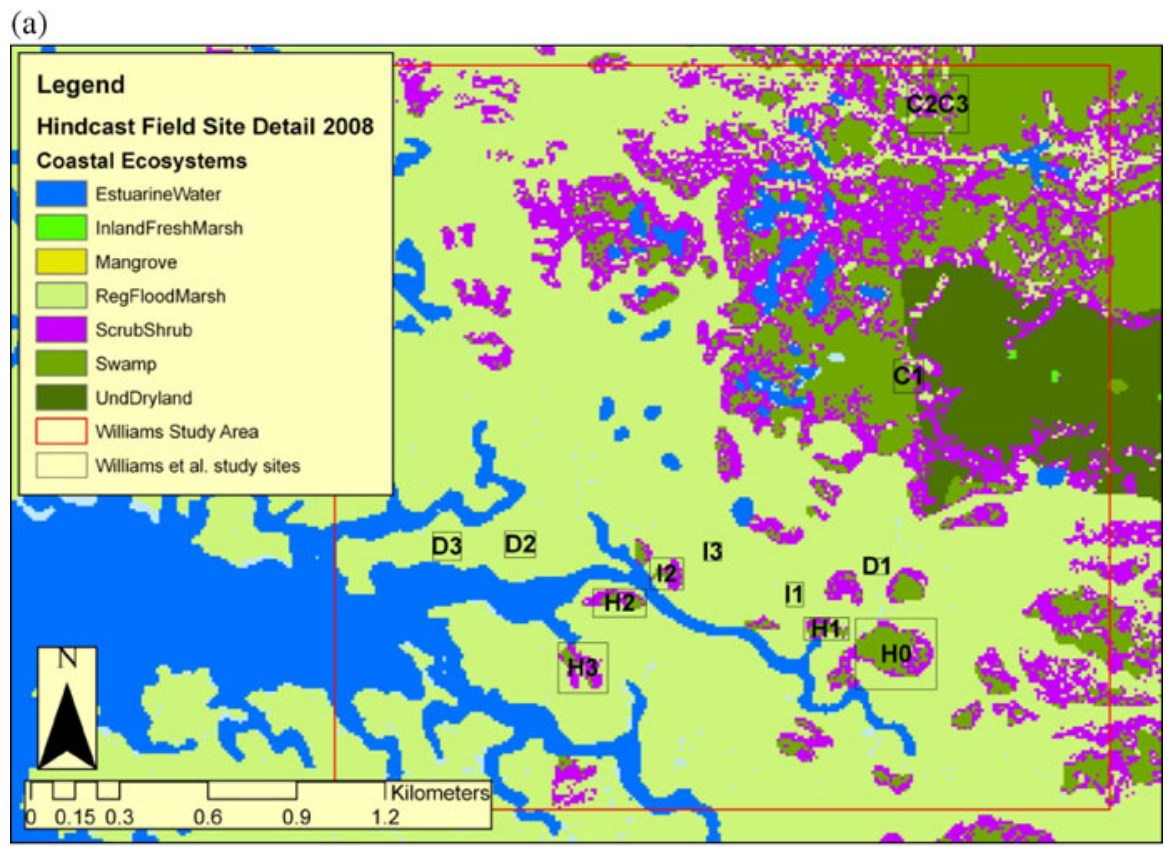

(b)

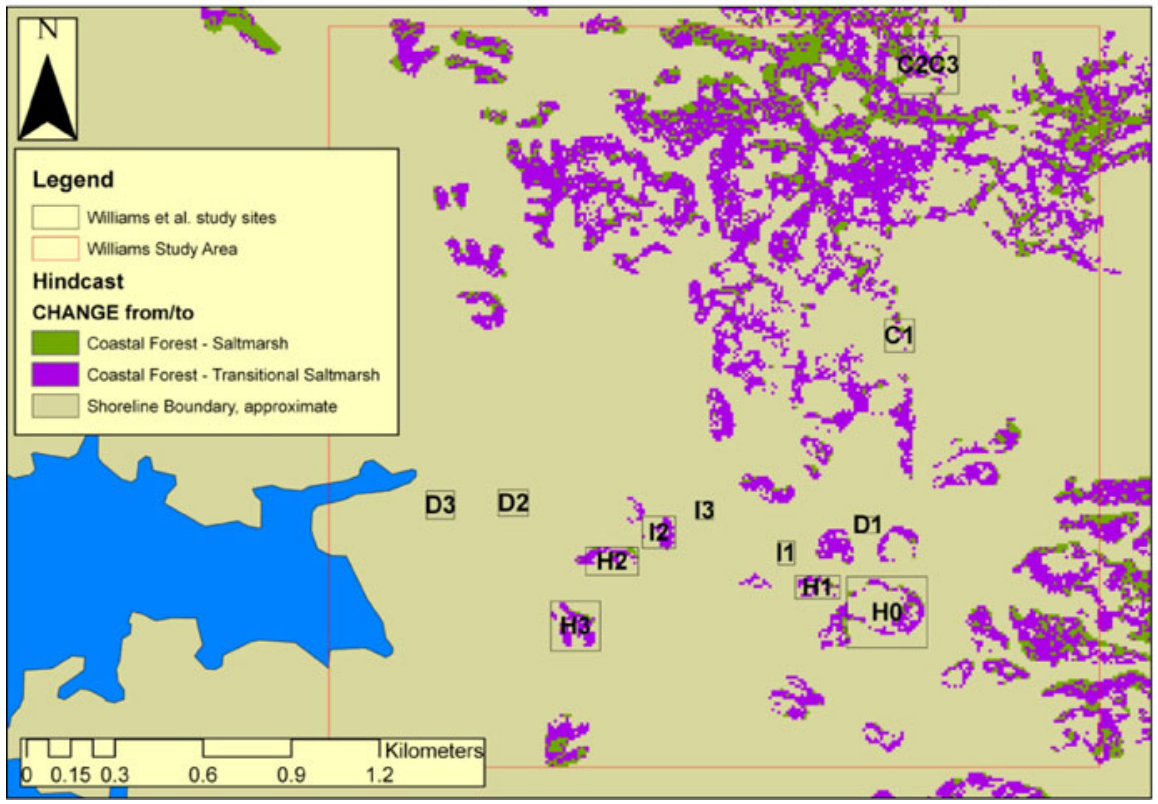

Fig. 4 Results of SLAMM hindcast 1984 to 2008 with field site detail. a Modeled distribution of coastal wetland systems in 2008. b Change in coastal wetland system distribution $>1 \%$ of the study area. Field plot labels from the Williams et al. (1999) study have the following meanings: $C$ plots are inland contiguous forest; $H, I$, and $D$ plots are forest (tree) islands surrounded by tidal creeks and saltmarsh of varying elevations. Based on the status of the canopy trees, particularly the presence of reproduction of these species, $H$ plots represented healthy stands, $D$ plots represented decadent stands, and $I$ plots represented forest stands in an intermediate condition between $\mathrm{H}$ and $\mathrm{D}$ plots 
Table 5 SLAMM prospective simulation modeling results for $0.64 \mathrm{~m}$ seal level rise scenarios, 2004 through 2100

\begin{tabular}{lrrrlrc}
\hline & IC & T0 & $\begin{array}{l}\text { IC to T0 \% } \\
\text { change }\end{array}$ & 2100 & $\begin{array}{l}\text { IC to 2100 } \\
\text { change }\end{array}$ & $\begin{array}{l}\text { IC to 2100 } \\
\% \text { change }\end{array}$ \\
\hline SLR (eustatic), m & 0 & 0 & & 0.5928 & & \\
$\begin{array}{l}\text { Developed dry land } \\
\text { Coastal wetland system }\end{array}$ & 66 & 66 & $0 \%$ & 62 & -4 & $-7 \%$ \\
$\quad$ Inland forest & 8,786 & 8,366 & $-5 \%$ & 5,876 & $-2,911$ & $-33 \%$ \\
Coastal forest & 10,094 & 6,987 & $-31 \%$ & 3,128 & $-6,966$ & $-69 \%$ \\
Cypress swamp & 29 & 29 & $-2 \%$ & 24 & -5 & $-17 \%$ \\
Inland freshwater marsh & 726 & 585 & $-19 \%$ & 549 & -177 & $-24 \%$ \\
Transitional salt marsh & 0 & 3,667 & & 8,823 & 8,823 & $42 \%$ a \\
Saltmarsh & 8,567 & 8,508 & $-1 \%$ & 9,645 & 1,078 & $13 \%$ \\
Mangrove & 155 & 153 & $-2 \%$ & 147 & -8 & $-5 \%$ \\
Estuarine beach & 14 & 14 & $2 \%$ & 11 & -3 & $-23 \%$ \\
Tidal flat & 233 & 291 & $25 \%$ & 272 & 39 & $17 \%$ \\
Inland open water & 95 & 62 & $-34 \%$ & 19 & -76 & $-80 \%$ \\
Estuarine open water & 2,483 & 2,103 & $-15 \%$ & 2,139 & -344 & $-14 \%$ \\
Open ocean & 27,183 & 27,599 & $2 \%$ & 27,737 & 554 & $2 \%$ \\
Brackish marsh & 50 & 50 & $0 \%$ & 50 & 0 & $0 \%$ \\
\hline
\end{tabular}

Units are in hectares unless otherwise noted. IC is initial condition. T0 is time zero (2004)

${ }^{a}$ Time zero rather than initial condition acreage was used for the percent change calculation as no transitional saltmarsh was recorded in the land cover dataset

Table 6 SLAMM prospective simulation modeling results for $1 \mathrm{~m}$ and $2 \mathrm{~m}$ sea level rise scenarios, 2004 through 2100

\begin{tabular}{lrrrrlrr}
\hline Scenario & All IC & $\begin{array}{l}1 \mathrm{~m} \\
2100\end{array}$ & $\begin{array}{l}1 \mathrm{~m} \mathrm{IC} \\
\text { to } 2100 \\
\text { change }\end{array}$ & $\begin{array}{l}1 \mathrm{~m} \mathrm{IC} \text { to } \\
2100 \% \\
\text { change }\end{array}$ & $\begin{array}{l}2 \mathrm{~m} \\
2100\end{array}$ & $\begin{array}{l}2 \mathrm{~m} \mathrm{IC} \\
\text { to } 2100 \\
\text { change }\end{array}$ & $\begin{array}{l}2 \mathrm{~m} \mathrm{IC} \text { to } \\
2100 \% \\
\text { change }\end{array}$ \\
\hline SLR (eustatic), m & 0 & 1 & & & 1.8524 & & \\
Developed dry land & 66 & 49 & -17 & $-25 \%$ & 14 & -53 & $-79 \%$ \\
Coastal wetland system & & & & & & & \\
$\quad$ Inland forest & 8,786 & 4,383 & $-4,403$ & $-50 \%$ & 1,016 & $-7,771$ & $-88 \%$ \\
Coastal forest & 10,094 & 1,692 & $-8,402$ & $-83 \%$ & 78 & $-10,016$ & $-99 \%$ \\
Cypress swamp & 29 & 19 & -10 & $-36 \%$ & 0 & -29 & $-99 \%$ \\
Inland fresh marsh & 726 & 427 & -299 & $-41 \%$ & 137 & -588 & $-81 \%$ \\
Transitional salt marsh & 0 & 3,669 & 3,669 & & 2,946 & 2,946 & \\
Saltmarsh & 8,567 & 17,515 & 8,948 & $104 \%$ & 4,470 & $-4,096$ & $-48 \%$ \\
Mangrove & 155 & 142 & -13 & $-8 \%$ & 2 & -153 & $-99 \%$ \\
Estuarine beach & 14 & 11 & -3 & $-24 \%$ & 0 & -14 & $-100 \%$ \\
Tidal flat & 233 & 562 & 330 & $142 \%$ & 9,159 & 8,927 & $3,837 \%$ \\
Inland open water & 95 & 11 & -84 & $-89 \%$ & 4 & -91 & $-96 \%$ \\
Estuarine open water & 2,483 & 2,215 & -268 & $-11 \%$ & 12,865 & 10,382 & $418 \%$ \\
Open ocean & 27,183 & 27,742 & 558 & $2 \%$ & 27,790 & 607 & $2 \%$ \\
Brackish marsh & 50 & 46 & -5 & $-9 \%$ & 0 & -50 & $-100 \%$ \\
\hline
\end{tabular}

Units are in hectares unless otherwise noted

IC initial condition, T0 time zero (in this case 2004) 
(SLAMM defines tidal flat strictly on relative elevation and tidal regime; Table 6). In this scenario, the area of inland forest decreases by $50 \%$.

Under the highest SLR scenario (2 m SLR by 2100), the model predicts a complete loss of estuarine beach and a nearly complete loss of coastal forest, cypress swamp, mangrove, and brackish marsh from the study area (Table 6). Substantial losses are also predicted for inland fresh marsh $(-81 \%)$ and saltmarsh $(-48 \%)$. In contrast, order(s) of magnitude increases are expected for tidal flats and transitional saltmarsh (+2946 ha). Other habitats expected to display substantial change include inland forest $(-88 \%)$ and estuarine open water $(+418 \%)$.

The spatial results predicted substantial transition of coastal forest to salt marsh and transitional saltmarsh under all prospective SLAMM scenarios (Figs. 5, 6 and 7). Under the $0.64 \mathrm{~m}$ SLR by 2100 scenario, the largest transitions are coastal forest to transitional saltmarsh, inland forest to transitional saltmarsh, coastal forest to saltmarsh, and inland forest to saltmarsh (Table 7). Under the $1 \mathrm{~m} \mathrm{SLR} \mathrm{scenario,}$ approximately 2700 ha more saltmarsh/transitional saltmarsh are expected to be present than under the $0.64 \mathrm{~m}$ scenario (21,184 ha versus 18,468 ha) with a modest increase in estuarine water area (approximately $112 \mathrm{ha}$ ). Under the $2 \mathrm{~m}$ SLR by 2100 scenario, SLAMM predicted a sharp increase in the area converted to estuarine water $(+10,382 \mathrm{ha})$ and a modest decrease in the area transitioning to saltmarsh/transitional saltmarsh (1150 ha).

\subsection{Comparison of prospective analyses}

Although SLAMM and the model developed to predict future coastal forest distribution by Castaneda and Putz (2007) both rely on elevation as the primary predictor of change, SLAMM's predictions are less conservative. Castaneda and Putz (2007) predicted that approximately $50 \%$ of coastal forest in the Park is expected to become saltmarsh by 2093 under a $0.64 \mathrm{~m}$ SLR. Our SLAMM analysis for the identical SLR rate found that $97 \%$ of the 1973 coastal forest in the Park (approximately 4100 ha) would transition to saltmarsh or transitional saltmarsh by 2100. This transition takes place throughout the Park's coastal forest area with only the highest elevation portions escaping transition even under this very conservative SLR scenario.

\subsection{Potential impacts of future SLR on vulnerable species}

Based on their habitat requirements, numerous rare species in Waccasassa Bay Preserve State Park are likely to be affected by SLR (Table 8). Species dependent on coastal forest may suffer the most impact. Although inland forests may accommodate some migration of coastal forest species, it is improbable that a well-developed coastal forest system will develop over the 100-year time frame.

Rare plant species affiliated with the coastal forests of Waccasassa Bay (Table 8) include anglepod (Matelea gonocarpos), Florida mayten (Maytenus phyllanthoides), pinewood dainties (Phyllanthus liebmannianus), and Florida pink-root (Spigelia loganioides). The latter is a narrow endemic known only from central Florida and occurs in association with exposed limestone that is a feature of the karstic geology of the area (Chafin 2000). Other karst-affiliated species in the study area include the Florida cave amphipod (Crangonyx grandimanus), Hobb's cave amphipod (Crangonyx hobbsi), and coastal lowland cave crayfish (Procambarus leitheuseri), all of 
(a)

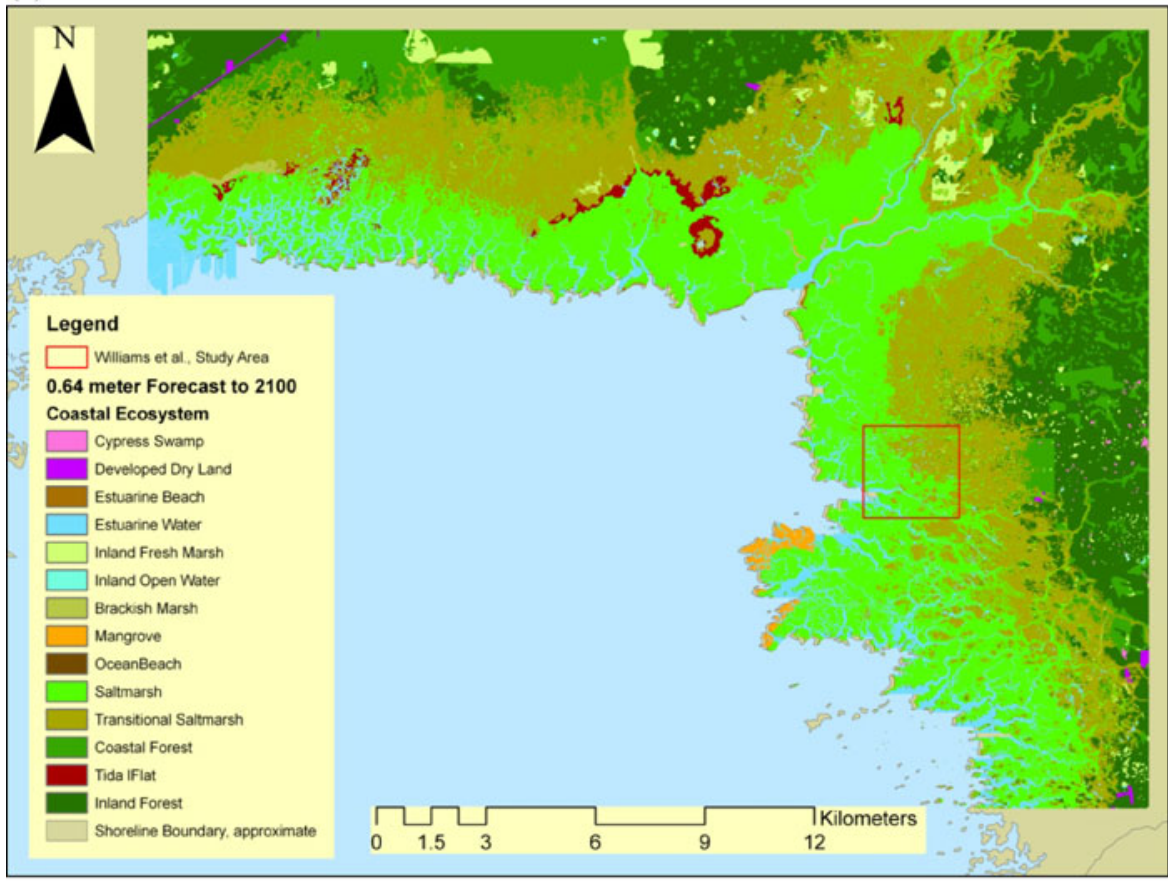

(b)

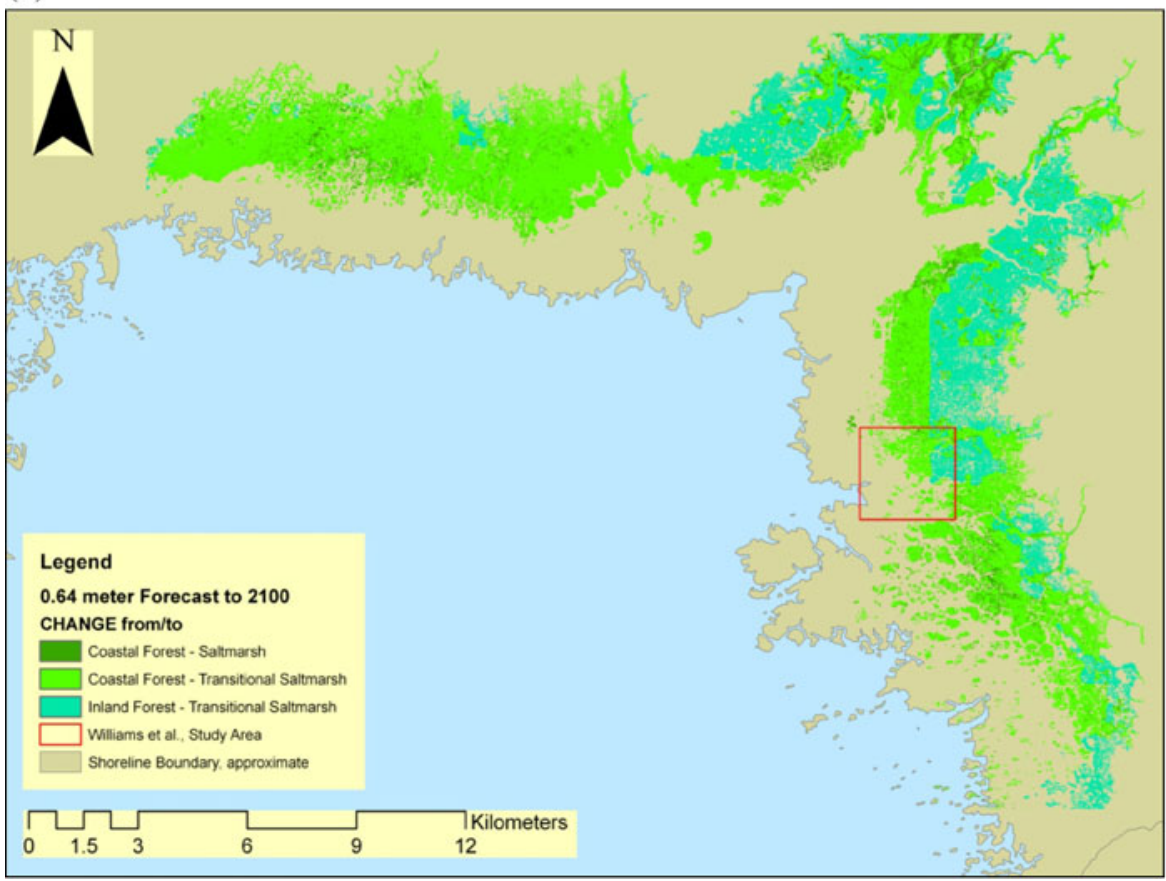

Fig. 5 Results of SLAMM forecast 2004 to 2100 with $0.64 \mathrm{~m}$ SLR. a Modeled distribution of coastal wetland systems in 2100 . b Change in coastal wetland system distribution $>1 \%$ of the study area 
(a)

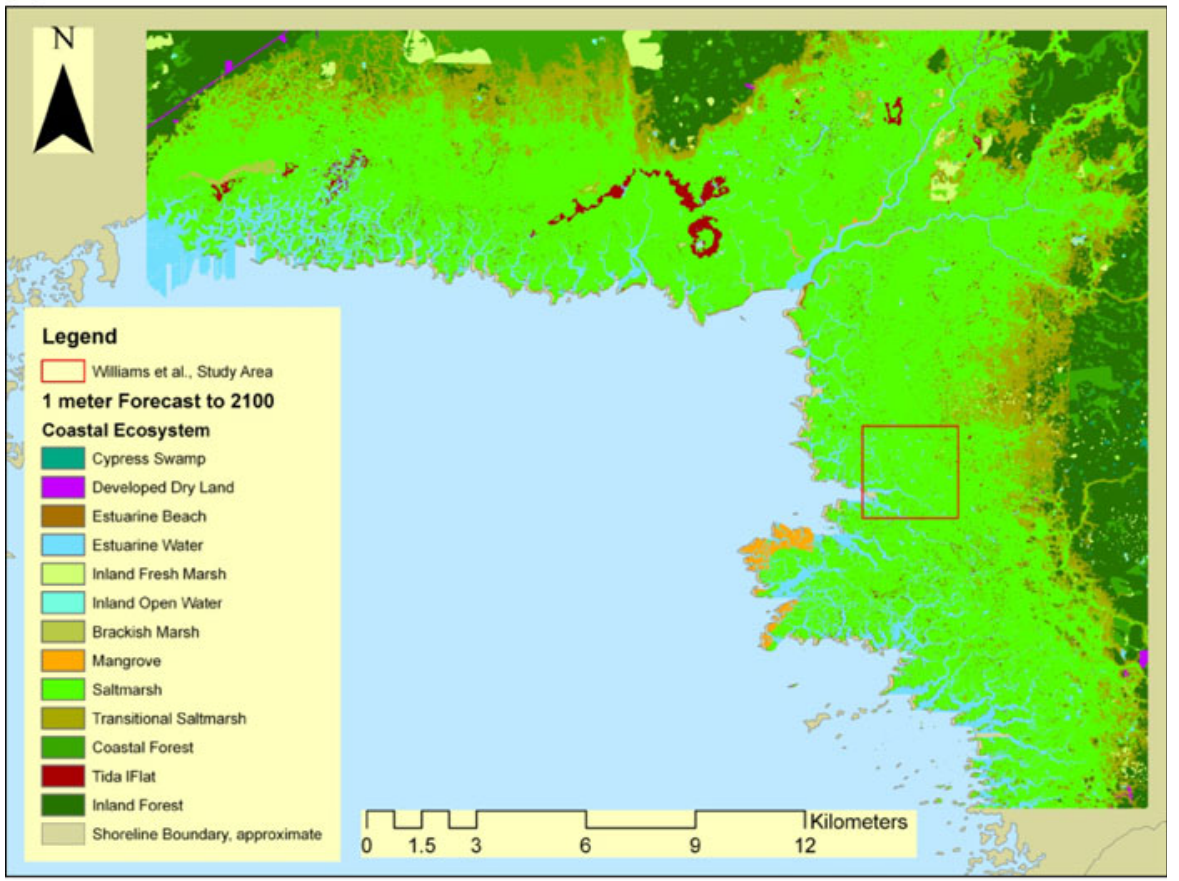

(b)

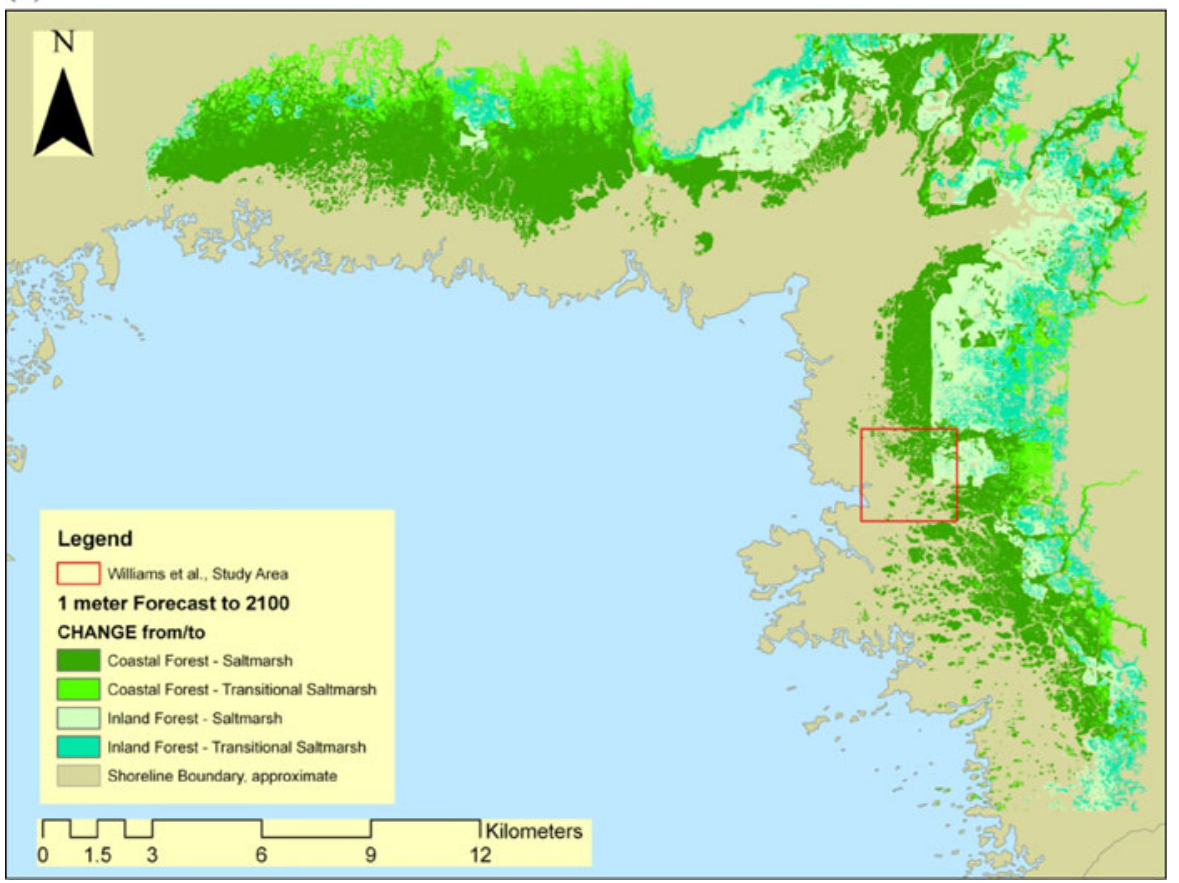

Fig. 6 Results of SLAMM forecast 2004 to 2100 with $1 \mathrm{~m}$ SLR. a Modeled distribution of coastal wetland systems in 2100 . b Change in coastal wetland system distribution $>1 \%$ of the study area 
(a)

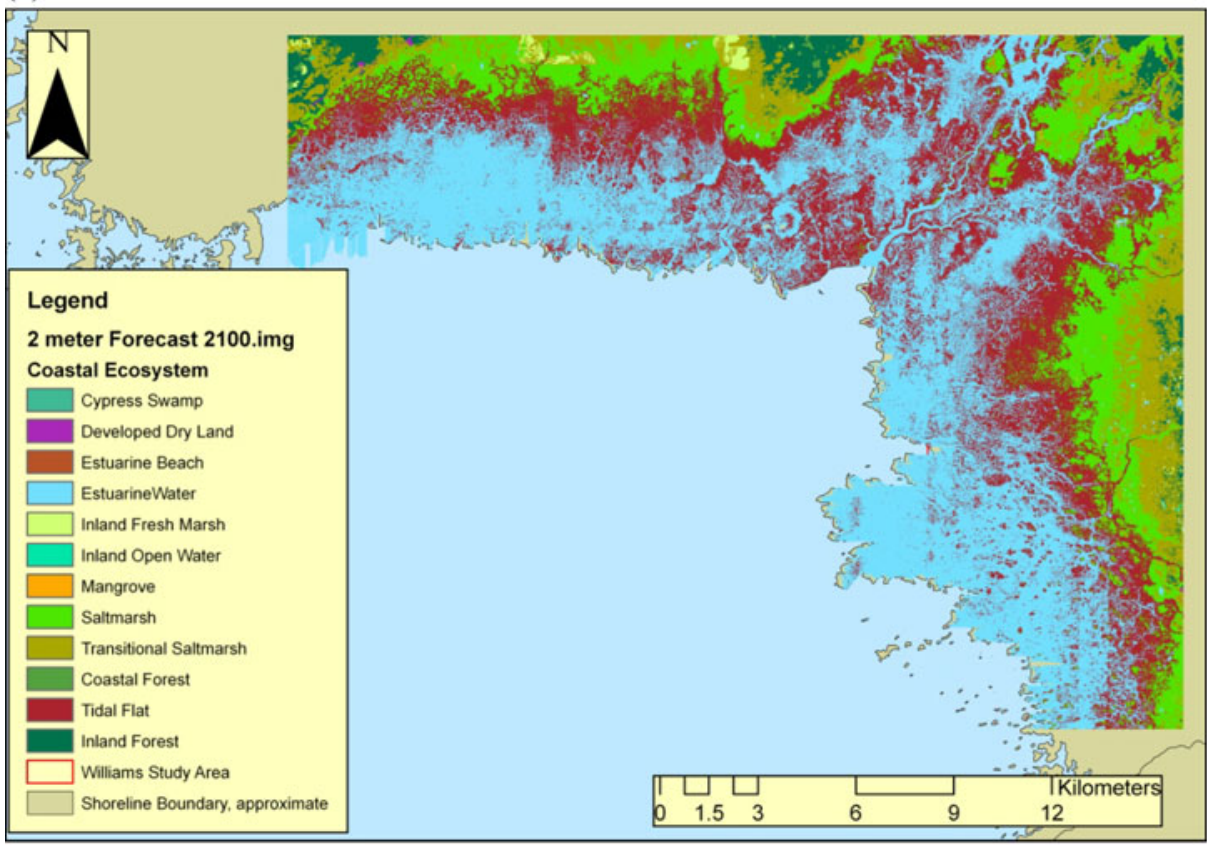

(b)

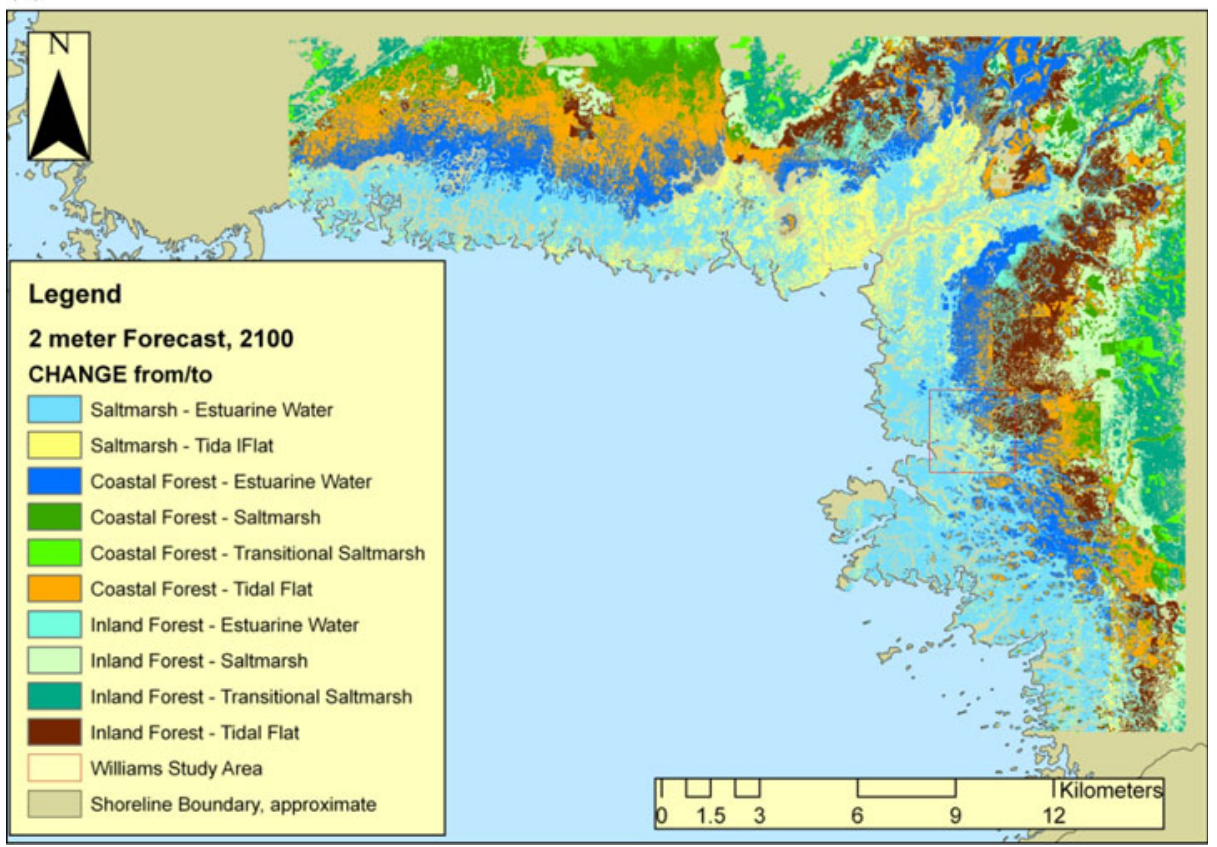

Fig. 7 Results of SLAMM forecast 2004 to 2100 with 2 m SLR. a Modeled distribution of coastal wetland systems in 2100 . b Change in coastal wetland system distribution $>1 \%$ of the study area 
Table 7 Change in coastal wetland systems within the study area for each prospective SLAMM scenario (units are in hectares)

Only changes representing $>1 \%$ of the study area are included

\begin{tabular}{|c|c|c|c|}
\hline Change from - to & $0.64 \mathrm{~m}$ & $1 \mathrm{~m}$ & $2 \mathrm{~m}$ \\
\hline Saltmarsh - estuarine water & - & - & 6,106 \\
\hline Coastal forest - tidal flat & - & 105 & 3,924 \\
\hline Coastal forest - estuarine water & - & - & 3,533 \\
\hline Inland forest - tidal flat & - & - & 2,575 \\
\hline Inland forest - saltmarsh & 195 & 2,602 & 2,417 \\
\hline Saltmarsh - tidal flat & - & 194 & 2,397 \\
\hline Inland forest - transitional saltmarsh & 2,715 & 1,779 & 2,095 \\
\hline Coastal forest - saltmarsh & 901 & 6,584 & 1,872 \\
\hline Coastal forest - transitional saltmarsh & 6,047 & 1,684 & 688 \\
\hline Inland forest - estuarine water & - & - & 687 \\
\hline
\end{tabular}

which are restricted to freshwater aquatic habitats that occur as small dissolution features within areas of exposed limestone. Although the karstic platform is exposed in some areas in Waccasassa Bay Preserve State Park inland from the coastal fringe, it is buried under deep sands further inland. Karst-dependent species will likely be

Table 8 Species with special listing status or of conservation interest due to endemism or perceived rarity that may be negatively affected by sea level rise in the study area

\begin{tabular}{|c|c|c|c|c|}
\hline Scientific name & Common name & Federal $^{\mathrm{a}}$ & State $^{\mathrm{b}}$ & FNAI $^{\mathrm{c}}$ \\
\hline \multicolumn{5}{|l|}{ Animals } \\
\hline Acipenser osyrinchus desotoi & Gulf sturgeon & $\mathrm{T}$ & SSC & G3T2/S2 \\
\hline $\begin{array}{l}\text { Ammodramus maritimus } \\
\text { peninsulae }\end{array}$ & Scott's seaside sparrow & & SSC & G3T3/S3 \\
\hline Amphiuma pholeter & One-toed amphiuma & & & $\mathrm{G} 3 / \mathrm{S} 3$ \\
\hline Aphelocoma coerulescens & Florida scrub-jay & $\mathrm{T}$ & $\mathrm{T}$ & $\mathrm{G} 2 / \mathrm{S} 2$ \\
\hline Floridobia helicogyra & Helicoid spring siltsnail & & & $\mathrm{G} 1 / \mathrm{S} 1$ \\
\hline Cistothorus palustris marianae & Marian's marsh wren & & SSC & G5T3/S3 \\
\hline Crangonyx grandimanus & Florida cave amphipod & & & G2G3/S2S3 \\
\hline Crangonyx hobbsi & Hobb's cave amphipod & & & $\mathrm{G} 2 \mathrm{G} 3 / \mathrm{S} 2 \mathrm{~S} 3$ \\
\hline Crotalus adamanteus & $\begin{array}{l}\text { Eastern diamondback } \\
\text { rattlesnake }\end{array}$ & & & $\mathrm{G} 4 / \mathrm{S} 3$ \\
\hline Drymarchon couperi & Eastern indigo snake & $\mathrm{T}$ & $\mathrm{T}$ & $\mathrm{G} 3 / \mathrm{S} 3$ \\
\hline Grus americana & Whooping crane & EXPN & SSC & G1 \\
\hline Haliaeetus leuсосерhalus & Bald eagle & & & G5/S3 \\
\hline Laterallus jamaicensis & Black rail & & & $\mathrm{G} 4 / \mathrm{S} 2$ \\
\hline Micropterus notius & Suwannee bass & & & \\
\hline $\begin{array}{l}\text { Microtus pennsylvanicus } \\
\text { dukecambelli }\end{array}$ & Florida saltmarsh vole & $\mathrm{E}$ & $\mathrm{E}$ & G5T1/S1 \\
\hline Mustela frenata olivacea & Southeastern weasel & & & G5T4/S3? \\
\hline Neovison vison halilimnetes & Gulf saltmarsh mink & & & G5T3/S3 \\
\hline Nerodia clarkia clarkii & Gulf saltmarsh snake & & & G4T4/S3? \\
\hline Procambarus leitheuseri & $\begin{array}{l}\text { Coastal lowland cave } \\
\text { crayfish }\end{array}$ & & & $\mathrm{G} 1 \mathrm{G} 2 / \mathrm{S} 1 \mathrm{~S} 2$ \\
\hline Trichechus manatus latirostis & Florida manatee & $\mathrm{E}$ & $\mathrm{T}$ & $\mathrm{G} 2 / \mathrm{S} 2$ \\
\hline Troglocambarus maclanei & $\begin{array}{l}\text { North Florida spider } \\
\text { cave crayfish }\end{array}$ & & & $\mathrm{G} 2 / \mathrm{S} 2$ \\
\hline Ursus americanus floridanus & Florida black bear & & $\mathrm{T}$ & $\mathrm{G} 5 \mathrm{~T} 2 / \mathrm{S} 2$ \\
\hline Villosa villosa & Downy rainbow mussel & & & \\
\hline
\end{tabular}


Table 8 (continued)

\begin{tabular}{|c|c|c|c|c|}
\hline Scientific name & Common name & Federal $^{\mathrm{a}}$ & State $^{b}$ & FNAI $^{\mathrm{c}}$ \\
\hline \multicolumn{5}{|l|}{ Plants } \\
\hline Anemone berlandieri & Texas anemone & & & \\
\hline Glandularia tampensis & Tampa vervain & & $\mathrm{E}$ & $\mathrm{G} 2 / \mathrm{S} 2$ \\
\hline Hasteola robertiorum & Florida hasteola & & $\mathrm{E}$ & $\mathrm{G} 1 / \mathrm{S} 1$ \\
\hline Helianthus debilis ssp tardiflorus & $\begin{array}{l}\text { Late flowering beach } \\
\text { sunflower }\end{array}$ & & & G3T3/S3 \\
\hline Leitneria floridana & Corkwood & & $\mathrm{T}$ & G3/S3 \\
\hline Listea aestivalis & Pondspice & & $\mathrm{E}$ & $\mathrm{G} 3 / \mathrm{S} 2$ \\
\hline Matelea gonocarpos & Anglepod & & $\mathrm{T}$ & \\
\hline Maytenus phyllanthoides & Florida mayten & & $\mathrm{T}$ & \\
\hline Opuntia stricta & Erect prickly pear & & $\mathrm{T}$ & \\
\hline $\begin{array}{l}\text { Phyllanthus liebmannianus ssp } \\
\text { platylepis }\end{array}$ & Pinewood dainties & & $\mathrm{E}$ & G4T2/S2 \\
\hline Spigelia loganioides & Pinkroot & & $\mathrm{E}$ & $\mathrm{G} 2 / \mathrm{S} 2$ \\
\hline
\end{tabular}

$E$ endangered, $T$ threatened, $S S C$ species of special concern, EXPN experimental population NonEssential, SSC Species of Special Concern, G1/S1 critically imperiled globally/in Florida because of extreme rarity (five or fewer occurrences or less than 1,000 individuals) or because of extreme vulnerability to extinction due to some natural or man-made factor, $G 2 / S 2$ imperiled globally/in Florida because of rarity (six to 20 occurrences or less than 3,000 individuals) or because of vulnerability to extinction due to some natural or man-made factor, $G 3 / S 3$ very rare and local throughout its range/in Florida (21-100 occurrences or less than 10,000 individuals) or found locally in a restricted range or vulnerable to extinction from other factors, $G 4 / S 4$ apparently secure globally/in Florida (may be rare in parts of range), G5/S5 demonstrably secure globally/in Florida, $G \#$ ?/S\#? tentative rank (e.g., G2?), G\#T\# rank of a taxonomic subgroup such as a subspecies or variety, $G$ portion of the rank refers to the entire species, $T$ portion refers to the specific subgroup, numbers have same definition as above (e.g., G3T1)

${ }^{a}$ Federal listings from the United States Fish and Wildlife Service (http://ecos.fws.gov/tess_public/)

${ }^{b}$ State listings for animal species from the Florida Fish and Wildlife Conservation Commission (http://myfwc.com/docs/WildlifeHabitats/Chapter_68A-27_final.pdf) and listings for plant species from the Florida Department of Agriculture and Consumer Services (https://www.flrules.org/ gateway/RuleNo.asp?title=PRESERVATION OF NATIVE FLORA OF FLORIDA\&ID=5B-40. 0055).

cFNAI rankings from the Florida Natural Areas Inventory (http://www.fnai.org/PDF/Element_ tracking_summary_201009.pdf)

eliminated from the study area. Furthermore, the aquatic species listed above may be eliminated by induced saltwater intrusion far in advance of actual inundation.

Rare species dependent on salt and brackish marshes include whooping crane (Grus americana), Scott's seaside sparrow (Ammodramus maritimus peninsulae), Marian's marsh wren (Cistothorus palustris marianae), black rail (Laterallus jamaicensis), Gulf salt marsh mink (Mustela vison haliaeetus), and Florida salt marsh vole (Microtus pennsylvanicus dukecambelli). Most of these species will probably persist in the study area due to the projected increases in the overall extent of their habitat, but species dependent on ecotonal habitats may be at risk. For example, the Marian's marsh wren is restricted largely to tall marsh bordering tidal creeks (Kale 1996). If transitional habitats are lost as sea levels rise, then such species may not persist despite the presence of large areas of salt marsh.

If development of high marsh habitat is inhibited by rapid SLR, all species dependent on high marsh and its ecotone with coastal forest may suffer despite the projected abundance of salt marsh and transitional salt marsh habitats. For example, 
corkwood (Leitneria floridana) is both coastal forest- and marsh-dependent because it occurs primarily at the ecotone between these communities. This species is unlikely to persist without a well-developed coastal forest canopy along the salt marsh edge. Similarly, the black rail is restricted primarily to the high marsh areas along forest edges.

The Florida salt marsh vole is known only from the salt marshes of Waccasassa Bay (Hipes et al. 2000) and is probably the most critically imperiled species in the study area. This species will merit special consideration in planning for the impacts of SLR along the Big Bend coastline. Intensive surveys should be conducted to identify more definitively the full extent of the species' range. While habitats are in flux, a captive breeding program for the vole could provide additional assurances that the species will persist. Fortunately, the vole has been bred in captivity and has a demonstrated ability to recolonize areas from which it was extirpated (Wood 1992).

The Florida black bear (Ursus americanus floridanus) and bald eagle (Haliaeetus leucocephalus) are dependent on the dense cover and well-developed canopy provided by the study area's coastal forests and may show local losses. Impacts to this Chassahowitzka sub-population of black bear could result from habitat fragmentation if private lands inland of the State Park are developed. At least 13 active bald eagle nests are present within areas that will be inundated by a $1 \mathrm{~m}$ rise in sea level, and it is unlikely the area of coastal forest predicted to remain would be sufficient to support a similarly high density of eagle nests. However, these pairs would likely relocate to pine-dominated forests located inland of the study area as long as productive coastal waters remain for foraging.

The analyses conducted in association with this study did not attempt to make predictions about the long-term population viability of species likely to be affected by sea level rise. Predictions about future population viability will require speciesspecific analyses that consider the range-wide extent and configuration of habitat located inland of the study area, as well as species-specific demographic factors. An analysis of future viability would also have to account for habitat lost to future human development. Owing to the remote and rural character of the Waccasassa Bay study area, future losses to development are predicted to be very low and total approximately 390 ha of inland forest by 2060 (Zwick and Carr 2006). This amounts to only $4 \%$ of the total inland forest present at initial condition.

\section{Discussion}

While the results of the SLAMM hindcast agree with field observations of the effects of SLR on the study area along the Gulf coast of Florida, SLAMM made some substantial adjustments to the initial conditions map (created from the NWI map; Table 3) based on the elevations at which coastal wetland system types are known to occur. For example, $30 \%$ of the coastal forest was adjusted to saltmarsh in the model based on the elevation input layer (derived from LiDAR). This suggests that much of the coastal forest may exist at elevations that are already being affected by historic SLR and are in the process of transitioning to salt marsh. This conversion process may take decades before the shift is noticeable. Williams et al. (2007) found that mature trees persist at least 30 years after reproduction has ceased because of salt stress. DeSantis et al. (2007) found that coastal forest 
in contiguous forest plots converted to saltmarsh at elevations in excess of $1 \mathrm{~m}$ NAVD88. Furthermore, populations of cabbage palms (Sabal palmetto), the most salt tolerant of the coastal forest tree species, were only viable at elevations $>0.66 \mathrm{~m}$ NAVD88. The SLAMM predictions, based on 52\% of the coastal forest in the study area occurring at elevations $<1 \mathrm{~m}$, may be foreshadowing community changes that are not yet apparent, but are biologically inevitable. The model predicts community composition when wetlands have come to equilibrium with a given sea level, meaning that it will not accurately predict short-term transitional effects.

SLAMM also predicted higher conversion of coastal forest into saltmarsh than predicted by Castaneda and Putz (2007). Differences in the elevation data used again likely explain much of this variation. Castaneda and Putz (2007) used radar elevation data from NASA's Shuttle Topography Mission (SRTM), which was found to have a mean vertical height error of $\pm 9 \mathrm{~m}$ in North America (Rodriguez et al. 2005), whereas the vertical accuracy of LiDAR elevation data in marsh and forest systems is $\pm 0.30 \mathrm{~m}$. Differences in results may also be explained by the different models used to predict vegetation change. The logistic model developed by Castaneda and Putz (2007) was based on field observations over a 30-year period. These data incorporate conditions not directly included in the SLAMM dataset, such as the vast amount of freshwater that transits the study area as the Floridan Aquifer discharges into the Gulf of Mexico. The effects of this freshwater head on the elevations at which coastal forest are still viable are unknown. However, SLAMM did predict the patterns observed in the field, verifying SLAMM's ability to capture many wetland processes under SLR conditions. Other factors potentially affecting SLAMM's ability to accurately portray changes in wetland size and distribution include changes in land use in the watershed such as those due to timber stand management and development, as well as variability in rainfall patterns.

Large areas of coastal wetland along the Gulf of Mexico are likely to be lost unless adjacent inland habitats are protected from development and hydrologic modification. Florida's Big Bend Gulf Coast, and in particular the Waccasassa Bay area, is among the relatively few areas in Florida where protection of adjacent uplands from development is still possible. Such protection efforts may increase the probability that rare species in this coastal system will remain viable. Where possible, these efforts should protect sufficient area to allow for the higher estimated rates of SLR because opportunities to protect undeveloped land will likely decrease over time. Protecting healthy coastal wetland systems in the face of SLR is even more important in light of the recent Gulf of Mexico oil spill. Coastal wetland systems in the areas of the greatest onshore impact from the spill will be substantially altered if not lost. The Gulf's remaining healthy coastal wetlands will serve as critical refugia for numerous species.

In addition to protection of upslope habitats, other management actions will be necessary to mitigate the effects of SLR on coastal wetland systems. Possible measures include the restoration and enhancement of oyster reefs as a way to reduce wave-generated erosion and enhance accretion of the sediments required to build salt marsh at the salt marsh-tidal flat transition zone (Meyer et al. 1997). Hydrologic restoration may be necessary in coastal wetlands systems that have been dredged for navigational or other purposes. Many other approaches for mitigating the loss of our highly productive coastal wetlands are being suggested (US EPA 2009; IPCC 1990). Regardless of the approaches adopted, mitigation and adaptation strategies need to 
be flexible so as to increase the probability that these coastal wetland systems and the services they provide will be conserved.

Acknowledgements The discussions at the Sea Level Rise Symposium held at Archbold Biological Station in January 2010 motivated this study. We appreciate access to the SLAMM 6.0.1 beta hindcast version and application assistance from Jonathan Clough. We also thank Kristin Ebersol, Manager of the Waccasassa Bay Preserve State Park, for input and valuable comments. This work was supported by the Florida Chapter of The Nature Conservancy.

Open Access This article is distributed under the terms of the Creative Commons Attribution Noncommercial License which permits any noncommercial use, distribution, and reproduction in any medium, provided the original author(s) and source are credited.

\section{References}

Castaneda H, Putz FE (2007) Predicting sea-level rise effects on a coastal nature preserve on the Gulf coast: a landscape perspective. Fla Sci 70:166-175

Chafin LG (2000) Field guide to the rare plants of Florida. Florida Natural Areas Inventory, Tallahassee

CCSP (2008) Abrupt Climate Change. A report by the US Climate Change Science Program and the Subcommittee on Global Change. (Clark PU, Weaver AJ, Brook E et al.) US Geological Survey, Reston, VA, p 459

Clough J, Park R, Fuller R (2010) SLAMM 6 beta technical document, release 6.0. Warren Pinnacle Consulting, Inc., $\mathrm{p} 41$

DeSantis LRG, Bhotik S, Williams K, Putz FE (2007) Sea-level rise and drought interactions accelerate declines of coastal forests on the Gulf Coast of Florida, USA. Glob Chang Biol 13:2349-2360

FDEP (2005) Waccasassa Bay Preserve State Park Unit Management Plan. Division of Recreation and Parks, Tallahassee

Glick P, Clough J (2006) An unfavorable tide - global warming, coastal habitats and sportfishing in Florida. National Wildlife Federation and Florida Wildlife Federation

Harris L, Cropper WP (1992) Between the devil and the deep blue sea: implications of climate change for wildlife in Florida. In: Peters RL, Lovejoy TE (eds) Global warming and biological diversity. Yale University Press, New Haven, pp 309-324

Hine AC, Belknap DF (1986) Recent geological history and modern sedimentary processes of the Pasco, Hernando, and Citrus county coastline: West-Central Florida. Florida Sea Grant Report 79. Florida Sea Grant, Gainesville, Florida

Hipes D, Jackson DR, NeSmith K, Printiss D, Brandt K (2000) Field guide to the rare animals of Florida. Florida Natural Areas Inventory, Tallahassee

IPCC (1990) Strategies for adaptation to sea level rise. Report of the Coastal Management Subgroup IPCC (2007) Climate Change 2007: The physical science basis, summary for policymakers. Contribution of working Group I to the fourth assessment report of the IPCC

Kale HW (1996) Marsh Wrens: Cistothorus palustris. In: Rodgers J, Kale H, Smith H (eds) Rare and endangered Biota of Florida, vol V. Birds. University Press of Florida, pp 602-607

Leonard LA, Hine AC, Luther ME (1995) Surficial sediment transport and deposition processes in a Juncus roemerianus marsh, West-Central Florida. J Coast Res 11.2:322-336

Meyer DL, Townsend E, Thayer G (1997) Stabilization and erosion control value of oyster cultch for intertidal marsh. Restor Ecol 5:93-99

Mitrovica JX, Gomez M, Clark PU (2009) The sea-level fingerprint of west Antarctica collapse. Science 323:753

Overpeck JT, Otto-Bliesner BL, Miller GH, Muhs DR, Alley RB, Kiehl JT (2006) Paleoclimatic evidence for future ice-sheet instability and rapid sea-level rise. Science 311:1747-1750

Park RA, Armentano TV, Cloonan CL (1986) Predicting the impact of sea level rise on coastal systems. In: Supplementary proceedings for the 1986 Eastern simulation conference, Norfolk, Virginia, pp 149-153

Rahmstorf S, Cazenave A, Church JA, Hansen JE, Keeling RF, Parker DE, Somerville RCJ (2007) Recent climate observations compared to projections. Science 316:709 
Rodriguez E, Morris CS, Belz JE, Chapin EC, Martin JM, Daffer W, Hensley S (2005) An assessment of the SRTM topographic products. Technical Report JPL D-31639. Jet Propulsion Laboratory, Pasadena

Suwannee River Water Management District (2006) MFL establishment for the Waccasassa River, Estuary and Levy (Bronson) Blue Spring. Technical Report

The Nature Conservancy and University of Florida Geoplan Center (2005) Florida peninsula ecoregional plan. Tallahassee and Gainesville, Florida

US Census Bureau (2010) http://www.census.gov/. Accessed 5 May 2010

US EPA (2009) Synthesis of adaptation strategies for coastal areas. Climate Ready Estuaries. http://www.epa.gov/cre/adaptationoptions.html

Williams K, Meads MV, Sauerbrey DA (1998) The roles of seedling salt tolerance and resprouting in forest zonation on the west coast of Florida, USA. Am J Bot 85:1745-1752

Williams K, Ewel C, Stumpf RP, Putz FE, Workman TW (1999) Sea-level rise and coastal forest retreat on the west coast of Florida, USA. Ecology 80:2045-2063

Williams K, Macdonald M, Sternberg LAL (2003) Interactions of storm, drought, and sea-level rise on coastal forest: a case study. J Coast Res 19:1116-1121

Williams K, Macdonald M, McPherson K, Mirti TH (2007) Ecology of the coastal edge of hydric hammocks on the Gulf Coast of Florida. In: Connor WH, Doyle TW, Krauss KW (eds) Ecology of tidal freshwater forested wetlands of the Southeastern United States. Springer, Dodrecht, pp 255-290

Wood CA (1992) Florida saltmarsh vole: Microtus pennsylvanicus dukecambelli. In: Humphrey S (ed) Rare and endangered biota of Florida, Volume 1: Mammals. University Press of Florida, pp 131-139

Zwick PD, Carr MH (2006) Florida 2060: a population distribution scenario for the State of Florida. Geoplan Center, University of Florida, Gainesville 